\title{
$1961-2013$ 年全球橡胶生产时空演变特征
}

\author{
肖池伟 ${ }^{1,2}$, 封志明 ${ }^{1}$, 李 鹏 $1^{*}$
}

(1. 中国科学院地理科学与资源研究所, 北京 $100101 ; 2$. 中国科学院大学, 北京 100049)

\begin{abstract}
摘 要: 橡胶生产关乎国计民生,特别是天然橡胶, 其与钢铁、石油、煤炭并称四大工业原料, 为重要的战略物资。本 文基于FAO橡胶数据库, 从全球、区域、国家等层次定量分析了 1961-2013 年全球橡胶生产的时空格局及其演变特 征, 探讨了影响橡胶产量的主要因素。结果表明: (1)从时间格局上看, 1961 年以来全球橡胶总产增速较快, 总体呈 上升趋势; 橡胶主要生产国(主产国)产量占全球的 $90 \%$ 以上, 并存在明显的阶段性增长特征。(2)就空间格局而言, 橡胶生产具有明显的地域集中性, 主产国集中分布在亚洲特别是东南亚, 其中以泰国、马来西亚和印尼最为集中, 但其产量差异显著并有进一步扩大趋势。(3)种植面积是主产国橡胶产量的主要影响因子; 少部分国家(如中国、泰 国)受橡胶单产水平的影响明显。(4)全球橡胶生产由传统“三巨头(泰国、马来西亚和印尼)”向“双核(泰国和印尼)” 集聚, 东南亚主产国橡胶林由海岛国家向中南半岛扩展, 且中南半岛发展势头强劲, 已成为全球橡胶主产区中的优 势产区。
\end{abstract}

关 键 词: 橡胶生产; 时空格局; 地域差异; 东南亚

\section{1 引言}

橡胶作为四大工业原料之一, 是一种重要的资 源约束型战略物质, 有天然与合成橡胶之分。天然 橡胶的市场价格和环境影响均低于合成橡胶 (Hicks et al, 2009), 且整体性能优于后者(Fox et al, 2013)。国际市场(如中国、美国、印度和日本等)对 橡胶特别是天然橡胶的需求势头强劲(Hicks et al, 2009; Evans et al, 2011), 促使热带地区非传统种植 国家纷纷发展橡胶种植业。天然橡胶作为不可或 缺、不可替代的工业原料,对国家产业发展、战略安 全具有重要意义。与此同时,全球市场对橡胶需求 的持续增长和区域经济一体化等促使了橡胶的扩 展种植。尽管橡胶种植面积与产量逐年增加, 但全 球天然橡胶已于 2004 年出现供给危机, 且有扩大的 趋势(Hicks et al, 2009)。随着全球市场对天然橡胶 的刚性需求, 世界范围内的橡胶生产规模还将持续
扩大(Dararath et al, 2011; Fox et al, 2013)。橡胶需 求的缺口促使热带地区一些非传统种植国家纷纷 发展本国橡胶种植业(Baird, 2010)。橡胶传统种植 区为赤道附近南北纬 $10^{\circ}$ 之间潮湿的热带地区, 如 泰国一马来半岛、马来西亚、印尼和印度等;而热带 其他地区通常称为橡胶非传统种植区 ( $\mathrm{Li}$ et al, 2012; Fox et al, 2013)。根据联合国粮农组织(FAO) 统计资料,迄今, 全球约 $95 \%$ 的橡胶园分布在亚洲, 其中 $75 \%$ 以上分布在印度尼西亚、泰国、马来西亚、 中国和印度。

世界经济的持续发展必然会增加对天然橡胶 的需求量, 尽管近几年世界经济增长的速度有所放 缓, 但对天然橡胶的需求量仍逐年增加。目前, 有 关橡胶研究主要集中在以下 4 个方面:(1)橡胶生产 国基础橡胶数据的收集与评估(张赛丽, 2011; 刘少 军等, 2015; 刘少军等, 2016), 主要是基于基础数据 采用时间序列等方法对影响橡胶种植的因素进行

收稿日期:2016-06;修订日期:2016-09。

基金项目: 国家自然科学基金项目 (41301090, 41271117) [Foundation: National Natural Science Foundation of China, No.41301090, No.41271117]。

作者简介: 肖池伟(1991-), 男, 湖北荆州人, 博士生, 主要从事资源利用与国土资源遥感研究,E-mail: xiaocw@igsnrr.ac.cn。 通讯作者:李鹏(1984-), 男,江西永新人,博士, 副研究员, 主要从事资源地理与国土资源遥感研究, E-mail: lip@igsnrr.ac.cn。 
了分析; (2)橡胶林的监测、扩展及种植格局(Liu et al, 2013; 封志明等, 2013; Li et al, 2015), 主要是利 用遥感手段基本厘清了老挝、缅甸等传统橡胶种植 区域和中国西双版纳等非传统种植区域的橡胶扩 展种植及动态变化; (3)橡胶的种植模式与经营方式 (李鹏等, 2016), 主要基于文献资料等对老挝国家层 面的橡胶扩展种植及其特征进行了全面梳理; (4) 橡 胶种植对社会经济和生态环境的影响(Mann, 2009; 高天明等, 2012), 主要探讨了橡胶生产、种植及对 天然森林等热带森林的挤压过程中,对区域资源、 生物多样性等造成的影响。而有关橡胶生产方面 的研究, 多为地区性或单一国家层面的研究, 如中 国海南与云南西双版纳(Dong et al, 2013)、老挝 (Laungaramsri, 2012)、泰国( $\mathrm{Li}$ et al, 2011)等。上述 成果多注重基础分析, 对国别之间的产量变化及对 比研究较少, 但仍为深人开展主产国橡胶生产的长 时间序列差异、空间格局特征及产量变化影响因素 研究奠定了数据基础与方法支撑。

全球约有 43 个国家种植天然橡胶,亚洲是天然 橡胶生产和需求最多的地区。特别地, 东南亚作为 全球天然橡胶的主产区和世界产胶中心, 其橡胶生 产对全球橡胶市场而言既是 “风向标”,也是 “晴雨 表”。东南亚不仅是中国一东盟自由贸易区(简称 东盟)的重要组成部分, 更是 21 世纪海上丝绸之路 的前沿阵地和重要枢纽。近年来, 随着美国实施 “重返亚太”战略, 日本推行“自由与繁荣之弧” 战 略, 印度推进 “东向行动” 战略, 欧盟和俄罗斯的战 略重心也向亚太地区的转移, 东盟正逐渐成为大国 角逐的对象和竞技场(Kitchen, 2012)。基于中国与 东盟的经贸联系日益加强及中国天然橡胶缺口日 益加大的现状, 研究当今全球最大橡胶需求国— 中国及世界最主要的橡胶产区之间的橡胶生产特 征, 对中国实施“走出去”和“引进来”战略、建设 21 世纪海上丝绸之路以及改善地缘安全环境具有重 要的现实意义。

随着社会经济的发展, 中国天然橡胶需求量正 逐年快速增长。继 2001 年成为全球最大的橡胶消 费和进口国以来, 橡胶的对外依赖程度不断加大。 国际天然橡胶市场受生产、消费、贸易和库存等因 素的影响, 其中生产是根本因素(封志明等, 2000)。 基于此,本文从全球近 53 年橡胶生产时空格局的角 度出发, 利用 FAO 的统计数据, 通过定量分析全球 主要橡胶生产国橡胶产量的波动特征, 从生产的角 度揭示橡胶产量的时空分布格局和区域差异, 探讨
主产国橡胶产量波动的主要影响因子,为促进中国 一东盟的橡胶战略合作与贸易作贡献,并为中国的 橡胶种植及进口提供科学依据和决策支持。

\section{2 研究区概况}

亚洲由东亚、东南亚、南亚、西亚、中亚和北亚 6 个亚区组成。其中东亚南部、东南亚、南亚季风气 候显著, 适宜橡胶的生长和种植, 该区也是亚洲乃 至全球天然橡胶的主要产地,主要包括泰国、印尼 和马来西亚等传统种植区和中国的西双版纳和海 南岛等橡胶改良种植区。特别地,按橡胶多年平均 产量超过 $10^{4} \mathrm{t}$ 计,东亚的中国,东南亚的泰国、越 南、缅甸、柬埔寨、菲律宾、马来西亚、印度尼西亚, 以及南亚的印度、斯里兰卡等 10 个国家为全球天然 橡胶的主要生产国家(简称“主产国”)(图 1)。

主产国土地面积为 1723.7 万 $\mathrm{km}^{2}$ (2014 年), 人 口约为 33.1 亿 (2014 年), 占全球总人口的 $50 \%$ 以 上。根据 FAO 统计资料, 1961-2013 年主产国橡胶 多年平均种植面积与产量分别占全球的 $92.13 \%$ 和 $92.21 \%$ 。与此同时, 中国已于 21 世纪初成为世界 上天然橡胶最大消费国,其需求量约占全球的 $25 \%$ (Hicks et al, 2009)。

\section{3 数据与方法}

\section{1 数据来源及处理}

根据 FAO 制定的 2010 年世界农业普查方案

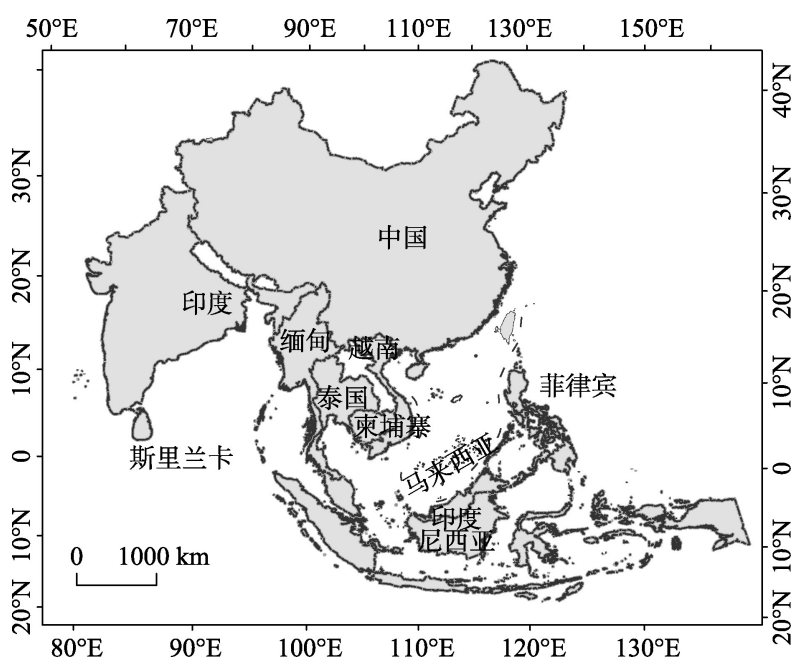

图 1 研究区地理区位图

Fig.1 Location of the major rubber-producing countries of Asian (MRPCA) 
(World Programmed for the Census of Agriculture), 农作物主要划分为九组(Group), 包括: 谷物(Cereals)、蔬菜和瓜类(Vegetables and Melons)、水果及坚 果(Fruit and Nuts)、油料作物(Oilseed Crops)、根/块 茎类作物(Root/Tuber Crops with High Starch or Inulin Content)、饮料和香料作物 (Beverage and Spice Crops)、豆科作物 (Leguminous Crops)、糖料作物 (Sugar Crops)和其他作物(包括橡胶、烟草等)。相应 地,每组又分为类(Class)与亚类(Sub-class)。

结合亚洲国家天然橡胶生产的实际情况, 本文 所用的橡胶数据均源自 FAO 粮食生产年鉴中的天 然橡胶(Rubber, Natural)数据库, 基础数据来源于联 合国粮食及农业组织统计年鉴(FAOSTAT, http:// faostat.fao.org/), 时间跨度为 1961-2013 年。其中, 橡胶的产量和单产数据均指天然橡胶产量(Rubber, Natural)。

\section{2 研究方法}

\subsection{1 橡胶总产量双因素分析}

双因素分析法用于分析 2 个因素的不同水平对 结果是否有显著影响, 以及 2 个因素之间是否存在 交互效应(有/无交互作用)。一般而言, 作物的总产 量受播种面积和单位生产水平的共同影响, 受气 候、作物等客观因素的制约, 两者的贡献存在一定 差异(封志明等, 2007; 肖池伟等, 2015)。本文通过 对影响橡胶总产量的种植面积和单产水平的分析, 探讨全球植胶面积与单产的影响因素, 以及不同国 别橡胶种植面积/单产水平对橡胶总产的差异。

\subsection{2 橡胶生产地区集中度指数}

集中度指数主要用来度量地理现象在空间或
时间上的集中程度(王伟红等, 2009)。本文用于衡 量区域橡胶种植情况，既能全面考察各个区域某种 作物总产量对该时期整个区域总产量的贡献程度, 同时选取时间序列数据, 又能比较各区域该作物生 产增长速度的差别。橡胶生产集中度指数是某时 期各地区橡胶总产量占整个地区总产量的比重, 其 公式为:

$$
M P R I=\frac{M R_{i}}{M R T_{i}}
$$

式中:MPRI指各个主产国的橡胶生产集中度指数; $M R_{i}$ 表示当年 $i$ 国家的橡胶生产产量; $M R T_{i}$ 表示当 年亚洲主产国的橡胶总产量。 $M P R I$ 越大, 说明该 国橡胶生产越具有优势, 对整个区域的贡献也 越大。

\section{4 结果与分析}

\subsection{1-2013 年橡胶产量变化特征}

橡胶总产量是衡量国家或地区橡胶总体生产 水平的主要指标, 区域橡胶产量的比重变化可以反 映橡胶生产区域格局的变化状况。1961-2013年全 球/主产国橡胶生产均取得了长足的发展, 总产增长 较快。近 53 年来, 主产国橡胶产量始终占全球产量 的 $90 \%$ 以上且存在明显的阶段性增长特征(图 2)。 细言之,1961-1978 年产量占比增长最快, 属于持续 上升期; 1978-20世纪末属于高值波动期,这一期间 亚洲经济增长较快, 对橡胶的需求量较大,但由于 经济增长的不稳定性导致橡胶生产处于高值波动 期;21世纪初-2013 年属于稳定回落期。

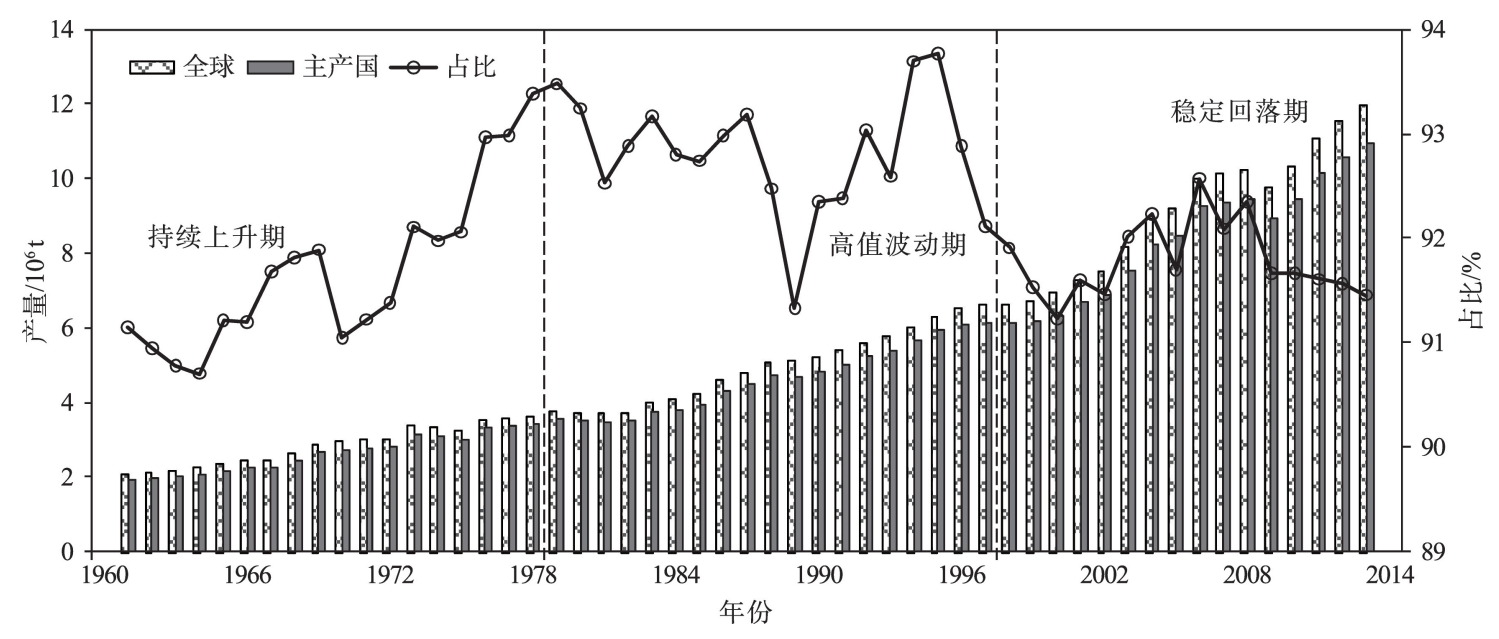

图 2 1961-2013年全球与亚洲主产国橡胶产量及比重变化情况

Fig.2 Temporal changes of the global and MRPCA rubber production and share, 1961-2013 
就全球范围来看, 世界橡胶总产量从 1961 年的 $2.12 \times 10^{6} \mathrm{t}$ 增加到 2013 年的 $11.97 \times 10^{6} \mathrm{t}$, 增长了 4.65 倍, 年均增长率为 $3.31 \%$, 整体呈现持续增长的态 势, 特别地, 自 2007 年起全球橡胶总产量突破千万 吨大关(图2)。

从亚洲主产国来看, 近 53 年以来, 橡胶总产量 整体呈上升趋势, 从 1961 年的 $1.93 \times 10^{6} \mathrm{t}$ 增加到 2013 年的 $10.94 \times 10^{6} \mathrm{t}$, 增加了 4.67 倍, 年均增幅为 $3.32 \%$ 。就主产国占全球总产量比重而言, 19612013 期间波动范围为 $90.71 \%$ 93.76\%, 平均占比为 $92.13 \%$, 并呈现出三大阶段性特征。具体言之, 由
1964 年的 $90.71 \%$ 快速上升到 1979 年的 $93.48 \%$; 到 20 世纪末期,稳定在 $92.78 \%$ 左右,其中 1995 年达到 最高峰, 为 $93.76 \%$; 至 21 世纪初回落到 2013 年的 91.46\%(图 2)。

就 10 个主产国而言,近 53 年各主产国橡胶产 量整体呈增加趋势,但占亚洲主产国的比重波动幅 度较大, 各国差异十分明显(图 3)。特别是泰国、马 来西亚和印尼作为亚洲主产国传统橡胶生产的三 巨头,多年平均产量占比高达 $81.26 \%$ 。

运用橡胶生产地区集中度指数 $(M P R I)$ 对主产 国橡胶产量比重变化情况进行梳理(图 3,表1),分

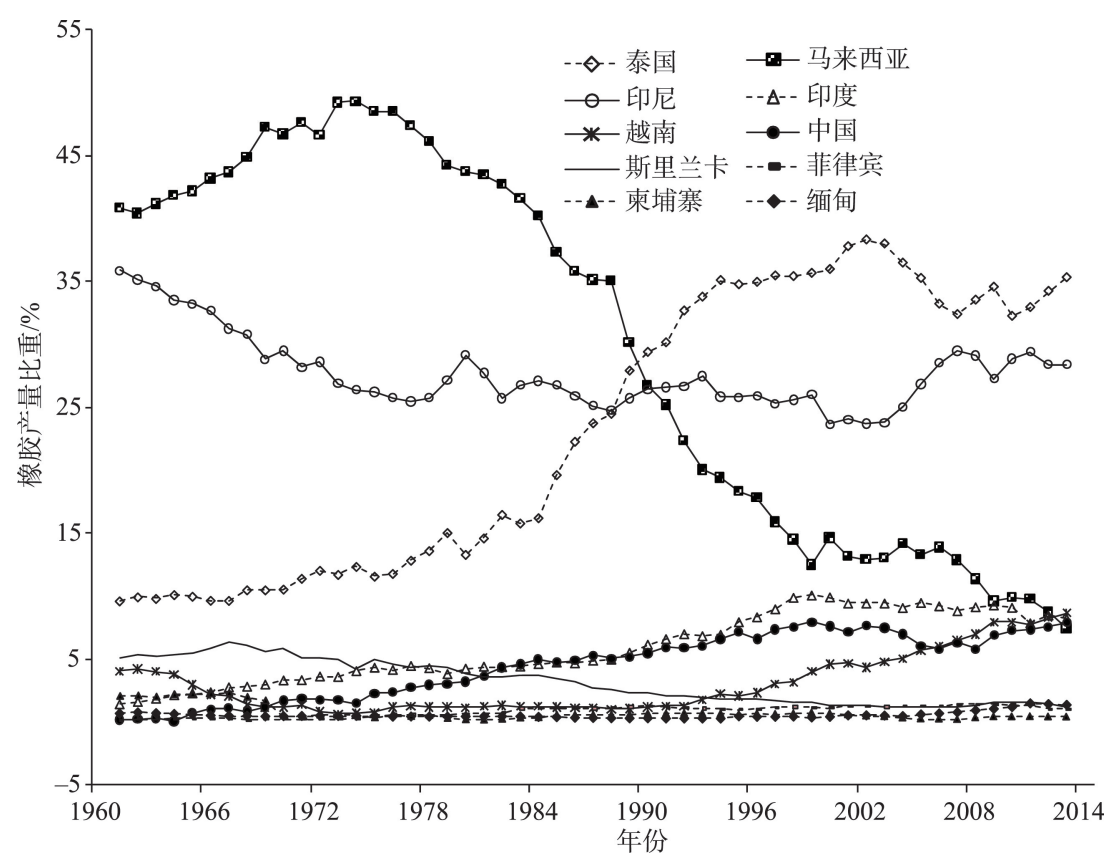

图 3 1961-2013 年亚洲各主产国橡胶产量比重变化情况

Fig.3 Proportions of rubber yield of the MRPCA, 1961-2013

表 1 1961-2013 年亚洲各主产国橡胶生产集中度指数变化情况/\%

Tab.1 Change of rubber production concentration index of the MRPCA, 1961-2013/\%

\begin{tabular}{|c|c|c|c|c|c|c|c|}
\hline 地区 & 国家 & 1961年 & 1970年 & 1980年 & 1990 年 & 2000年 & 2013 年 \\
\hline \multirow[t]{7}{*}{ 东南亚 } & 泰国 & 9.63 & 10.56 & 13.31 & 29.39 & 35.95 & 35.30 \\
\hline & 柬埔寨 & 2.07 & 0.47 & 0.17 & 0.66 & 0.67 & 0.39 \\
\hline & 缅甸 & 0.69 & 0.48 & 0.45 & 0.31 & 0.41 & 1.35 \\
\hline & 越南 & 4.04 & 1.21 & 1.17 & 1.20 & 4.59 & 8.67 \\
\hline & 马来西亚 & 40.86 & 46.69 & 43.78 & 26.76 & 14.64 & 7.55 \\
\hline & 印尼 & 35.87 & 29.50 & 29.19 & 26.43 & 23.69 & 28.40 \\
\hline & 菲律宾 & 0.19 & 0.23 & 0.64 & 1.27 & 1.13 & 1.02 \\
\hline \multirow[t]{2}{*}{ 南亚 } & 印度 & 1.40 & 3.31 & 4.25 & 6.16 & 9.94 & 8.22 \\
\hline & 斯里兰卡 & 5.05 & 5.85 & 3.81 & 2.34 & 1.38 & 1.19 \\
\hline 东亚 & 中国 & 0.20 & 1.70 & 3.23 & 5.48 & 7.60 & 7.91 \\
\hline
\end{tabular}


析发现: 1961-2013 年间,除印尼产量较稳定外;马 来西亚、柬埔寨、斯里兰卡 3 国的橡胶产量比重均表 现出下降的态势, 减幅分别为 $81.52 \% 、 81.16 \%$ 与 $76.44 \%$, 其中, 马来西亚产量占比的绝对减少量 (33.31\%) 尤为明显; 其他6个主产国的橡胶产量占 比相对期初(1961 年)总体上均有不同幅度的上升, 增幅最大与最小的分别为中国 (38.55 倍)与缅甸 (0.96倍)。从不同国家的 MPRI变化看, 泰国年均增 长达 $25.7 \%, 2013$ 年跃居第 1 位, 产量占比达 $35.30 \%$; 马来西亚则波动额度最大, 从 1961 年的 $40.86 \%$ 下滑到 2013 年的 $7.55 \%$, 其在世界的位次也 相应地从第 1 位降至第 6 位; 印尼则稳居第 2 位, 稳 定在 30\%左右; 越南则从第 5 位攀升到第 3 位, 2013 年产量占比为 $8.67 \%$; 中国则由第 9 位上升至第 5 位, 2013 年产量占比为 $7.91 \%$; 印度和斯里兰卡分 别从第 $7 、$ 第 4 位变为第 4 、第 8 位; 缅甸、柬埔寨和菲 律宾的 MPRI 和名次相对变化不大。上述主产国橡 胶产量变化表明, 中南半岛国家占比逐渐上升且总 比重具有优势, 而与此对应的是东南亚海岛国家产 量占比下降较为明显, 这表明中南半岛比马来群岛 在橡胶扩展种植上更具发展潜力。

就亚洲三大亚区(东亚、南亚、东南亚)的产量占 比而言, 差异较大且随时间的推移呈现出不同特征 (表 1)。主产国中, 虽东南亚各国产量仍占绝对优 势, 但非东南亚国家的比重从 1961 年的 $6.65 \%$ 上升 到 2013 年 $17.32 \%$ 。其中, 南亚国家呈波动上升之 势, 占比从 1961 年的 $6.45 \%$ 上升到 2000 年 $11.32 \%$, 后又回落至 2013 年的 $9.42 \%$; 东亚国家(中国)占比 虽较小, 但表现出持续上升的特征, 从 1961 年的 $0.20 \%$ 上升至 2013 年的 $7.90 \%$ 。

由表 1 可知, 东南亚半岛四国(泰国、柬埔寨、缅 甸、越南)成为主产国中新的橡胶产量大国, 占比扩 大近三成, 特别地, 中南半岛国家的泰国占比增长 最快。此外, 半岛国家的非主产国一一老挝近年来 橡胶林扩展种植势头明显, 步人了举国发展橡胶种 植业的高潮(李鹏等, 2016); 而东南亚海岛三国总体 占比下降近一半, 其中马来西亚占比下降最大; 南 亚两国中, 印度产量占比增长较明显, 而斯里兰卡 则下降幅度较大; 东亚的中国则呈持续上升的强劲 态势, 反映出中国对橡胶的需求急迫, 但橡胶生产 则受制于国内宜植胶面积较少(Liu et al, 2013)而产 量在全球占比仍不足 $8 \%$, 未来, 向周边国家的扩展 种植和开展橡胶合作才是关键。
值得注意的是, 位于中南半岛的泰国、越南作 为 20 世纪末期崛起的橡胶生产后起之秀, 其橡胶产 量日益剧增,两国的 MPRI 从 1961 年的 $13.67 \%$ 增长 到 2013 年的 $43.97 \%$, 现已成为全球橡胶主产区中 的产胶大国。相应地, 在 1961-2013 年间中国得益 于橡胶单产的大幅提高, 橡胶产量增长了近 230 倍, 但由于受气候条件所限, 橡胶宜林地有限(Liu et al, 2013), 因而目前总产尚不足泰国的 1/4。今后在进 一步提高单产的同时,应加强与东南亚各国橡胶生 产和贸易合作, 特别在中老缅交界的老挝与缅甸, 合作开发橡胶宜林地的潜力巨大, 这也与此前利用 遥感手段监测结果相一致(封志明等, 2013)。

\section{2 主产国橡胶产量变化影响因素}

基于数据的可获取性,本文对影响橡胶总产量 的种植面积与单产水平进行了初步梳理及分析; 在 此基础上, 对全球和主产区不同国别的橡胶总产 量、种植面积和单产水平进行分析, 进而探讨影响 橡胶总产量变化的主要因素。

从全球来看, 1961-2013年, 橡胶总产和橡胶种 植面积的变化总体较为一致, 相关性达 0.98 , 即种 植面积的变化和橡胶总产量的变化基本同步; 相较 而言, 橡胶单产水平对总产的影响不太明显; 直到 20 世纪末-21世纪初,伴随橡胶单产的快速提升, 单 产从 21 世纪末以前的 $650 \mathrm{~kg} / \mathrm{hm}^{2}$ 左右提高到 21 世 纪初的近 $1000 \mathrm{~kg} / \mathrm{hm}^{2}$, 单产开始对全球橡胶总产量 产生较大影响,特别受泰国和中国的单产提高影响 较明显(两国单产分别提高 2.37、1.41 倍)。总体来 说,近 53 年来全球橡胶种植面积的变化对橡胶总产 量的影响和贡献较大, 但自 20 世纪末起, 橡胶单产 水平的提高对世界橡胶总产量的影响和贡献日益 凸显。未来的重点应立足于稳定和适度扩展植胶 面积的前提下, 进一步提高单产水平, 以此促进全 球橡胶总产量的持续增长。

从 10 个主产国的情况看, 缅甸和柬埔寨受种植 面积和单产水平共同的波动影响; 马来西亚、印尼、 越南、菲律宾、斯里兰卡的橡胶种植面积与橡胶总 产量之间拟合较好, 即大部分主产国橡胶产量主要 受种植面积的影响。2013 年, 上述五国橡胶种植面 积占主产国的 $59.13 \%$; 产量为 $5.12 \times 10^{6} \mathrm{t}$, 占主产国 总量的 $46.83 \%$ 。印度、中国、泰国三国橡胶单产水 平与橡胶总产量相关性更强, 2013 年占主产国植胶 面积的 38.28\% , 却贡献了主产国橡胶产量的 $51.42 \%\left(5.63 \times 10^{6} \mathrm{t}\right)$, 表明其橡胶总产量变化主要受 
单产水平的影响。相关研究表明(Liu et al, 2013; 封 志明等, 2013), 中国橡胶主要种植区一一西双版纳 的橡胶种植的海拔已经突破 $1000 \mathrm{~m}$ (适宜海拔为 600 800 m), 相较扩大种植面积而言, 今后提高单 产可能是最主要的途径; 越南等热带森林资源丰 富、宜植胶面积广的国家(郭又新, 2011), 受制于科 学技术, 通过开垦新宜林地种植橡胶远比其提高单 产水平更为可行(近年来其橡胶种植面积扩展近 5 倍)。此外, 其他主要橡胶生产国中, 缅甸和柬埔寨 因国家政局不稳定, 加之国内经济不景气等因素的 影响,使得橡胶生产呈现较大的波动特征。

\section{3 橡胶生产的空间格局与地域特征}

结合 1961-2016 年亚洲主产国橡胶产量资料, 选取 1961、1980、2000 年和 2013 年 4 个时间节点的 数据, 以 2013 年为基础对其余 3 个年份的数据进行 归一化处理, 在此基础上, 利用 ArcGIS 操作平台进 行空间分析。就地理区域而论, 近 53 年来主产国橡 胶产量的国别差异显著。在橡胶总产不断增加的 背景下, 各国家差距进一步扩大(图 4, 表 1), 全球尺 度上逐渐向东南亚国家集中, 而东南亚地区从传统
的橡胶生产“三巨头(泰国、马来西亚和印尼)”演变 为“双核(泰国和印尼)”结构。

从 10 个橡胶主产国的空间分布来看(图 4), 近 53 年来主产国橡胶生产基本稳定且具有明显的地 域集中性, 其中, 泰国、马来西亚和印尼始终位居前 三甲。1961 年橡胶产量超过 50 万 $\mathrm{t}$ 的国家仅有马 来西亚和印尼(图 4a), 其他国家的产量均在 10 万 $\mathrm{t}$ 以下, 中国和菲律宾则低于 1 万 $\mathrm{t} ; 1980$ 年, 大部分主 产国橡胶产量在 10 50万 $\mathrm{t}$ 之间(图 4b), 超过 50 万 $\mathrm{t}$ 的国家仍然是马来西亚和印尼, 柬埔寨的橡胶产量 跌出 1 万 $\mathrm{t}$, 中国橡胶产量增长明显; 2000 年, 主产国 橡胶产量普遍增加(图 4c), 超过 50 万 $\mathrm{t}$ 的国家有泰 国、马来西亚、印尼和印度四国, 其中泰国橡胶产量 超过 200 万 $\mathrm{t}$, 居各国之首;2013 年, 大部分主产国橡 胶产量在 50 万 $\mathrm{t}$ 以上(图 4d), 其中, 泰国和印尼的总 产优势十分明显, 分别超过 350 、300万 $\mathrm{t}$ 。

从近 53 年主产国橡胶产量的变化看, 19612013 年 7 个国家(中国、印度、泰国、缅甸、菲律宾、马 来西亚、印尼)的橡胶产量一直增加, 2 个国家(越南、 柬埔寨)的橡胶产量先减少后增加,斯里兰卡的橡
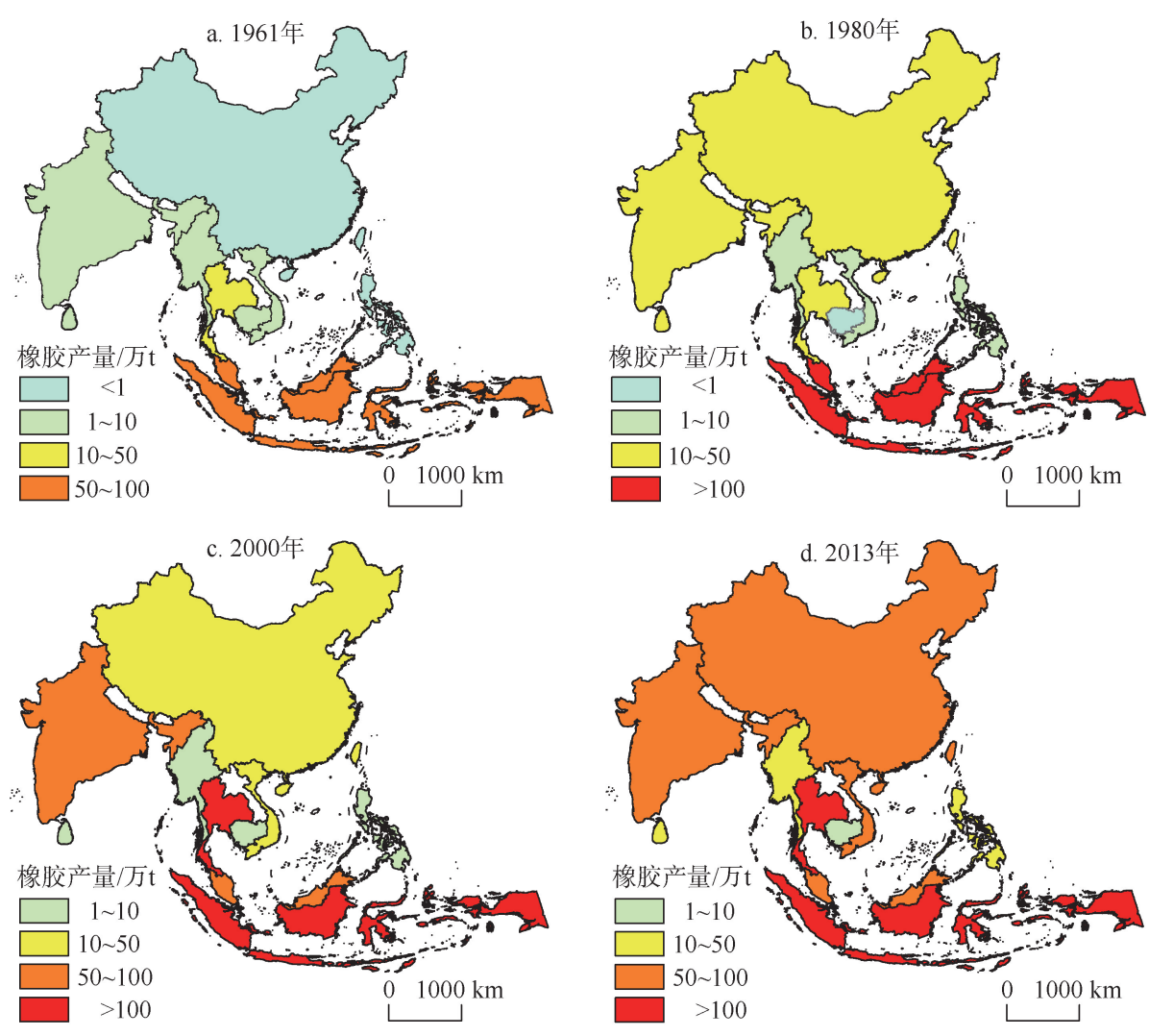

图 4 1961-2013 年主产国橡胶总产量空间分布与格局变化

Fig.4 Spatial patterns and distribution of rubber production in the MRPCA,1961-2013 
胶产量先增加后减少再增加。橡胶种植的重心向 中南半岛倾斜, 特别是向泰国、越南的推移尤为明 显。一方面, 中南半岛毗邻全球最大橡胶需求国 (中国), 消费市场广阔, 橡胶扩展种植地缘优势明 显; 另一方面, 东南亚海岛国家利用丰富的光、热、 水及土地资源大力发展对自然条件要求更为严格 的油棕, 以此替代橡胶种植(Hicks et al, 2009), 继而 导致橡胶种植减缓, 驱使橡胶种植北移。此外, 老 挝、缅甸等传统橡胶种植国, 受价格驱动以及 “猺粟 替代种植”政策影响 (Liu et al, 2013; 封志明等, 2013), 橡胶种植面积进一步扩大。

\section{5 结论与讨论}

\section{1 结论}

本文以 FAO 数据库的数据为基础, 运用双因素 分析和集中度指数等方法, 定量分析了 1961-2013 年全球主要橡胶生产国橡胶生产的时空格局及其 演变特征, 并探讨了橡胶产量动态变化的主要影响 因素,研究表明:

(1) 1961-2013 年, 全球橡胶总产量呈上升趋 势, 橡胶总产量在 2007 年突破千万吨大关; 近 53 年 来, 主产国橡胶总产量增加了 4.67 倍, 其橡胶产量 始终占全球总产量的 $90 \%$ 以上, 且存在明显的阶段 性增长特征。

(2) 从全球来看, 1961-2013 年橡胶总产量和种 植面积的变化总体较为一致, 种植面积是橡胶总产 量增长的主要影响因子; 21 世纪初, 随着橡胶单产 水平的快速提高,单产对橡胶总产量的影响凸显。 就国别而言, 大部分主产国(如马来西亚、印尼等)橡 胶总产量的影响因素为种植面积, 少部分国家(如 中国、泰国等)橡胶总产受单产水平提高的影响 较大。

(3) 从空间分布及变化来看, 全球主要橡胶生 产国基本稳定且空间分布具有明显的地域集中性, 其中, 泰国、马来西亚和印尼始终位居前三位; 近 53 年来, 主产国橡胶产量国别差异显著, 各国的差距 进一步扩大, 中南半岛成为橡胶主产区中的优势产 区, 且未来发展潜力巨大。

\section{2 讨论}

橡胶作为重要的稀缺性战略物质, 其对社会经 济发展的重要意义不言而喻。近年来, 东南亚地区 作为全球橡胶的主产区, 已成为国际关注的热点区
域,也是美、日、印、中等大国角逐的场所。在此地 缘政治背景下, 中国为谋求在该区域的政治、经济 及外交等方面的话语权,未来同该区域的合作、交 流与联系必将日益频繁。面对复杂的东南亚局势, 研究其橡胶生产的时空演变特征, 对作为橡胶消费 大国的中国制定橡胶发展规划和加强橡胶生产与 贸易的战略合作具有重要意义。特别是随着中国 经济的持续稳定增长和汽车工业的快速发展, 对橡 胶的需求量不断增长。因此, 中国实施橡胶生产的 “走出去”和“引进来” 战略, 以及推进“21世纪海上 丝绸之路”共建, 对稳定橡胶的安全供应具有重要 的现实意义。

基于数据的可获取性等原因, 本文仅对橡胶产 量、种植面积、单产水平等影响区域橡胶产量的因 素进行了定量分析与初步探讨。实际上, 影响橡胶 产量变化的因素还包括市场需求、生产周期(种植/ 幼林一产胶/成林一割胶)、耕地面积、种植结构、技 术水平及国际石油价格的周期波动等。此外,橡胶 生产还应考虑橡胶的贸易、库存及国家间的战略决 策等因素。未来将在此基础上,作进一步的深人 研究。

\section{参考文献(References)}

封志明, 李香莲. 2000. 耕地与粮食安全战略: 藏粮于土, 提 高中国土地资源的综合生产能力 $[\mathrm{J}]$. 地理学与国土研 究, 16(3): 1-5. [Feng Z M, Li X L. 2000. The stratagem of cultivated land and food supplies security: Storing food in land- raising the comprehensive productivity of land resource of China[J]. Geography and Territorial Research, 16 (3): 1-5.]

封志明, 刘晓娜, 姜鲁光, 等. 2013. 中老缅交界地区橡胶种 植的时空格局及其地形因素分析 [J]. 地理学报, 68(10): 1432-1446. [Feng Z M, Liu X N, Jiang L G, et al. 2013. Spatial-temporal analysis of rubber plantation and its relationship with topographical factors in the border region of China, Laos and Myanmar[J]. Acta Geographica Sinica, 68 (10): 1432-1446.]

封志明, 杨艳昭, 张晶, 等. 2007. 从栅格到县域: 中国粮食生 产的资源潜力区域差异分析 [J]. 自然资源学报, 22(5): 747-755. [Feng Z M, Yang Y Z, Zhang J, et al. 2007. A GIS based study on the grain productivity and potential yield increase at multi-levels in China[J]. Journal of Natural Resources, 22(5): 747-755.]

高天明, 沈镭, 刘立涛, 等. 2012. 橡胶种植对景洪市经济社 
会和生态环境的影响 [J]. 资源科学, 34(7): 1200-1206.

[Gao T M, Shen L, Liu L T, et al. 2012. The impacts of rubber plantation on society, economy and eco-environment in Jinghong City[J]. Resources Science, 34(7): 1200-1206.] 郭又新. 2011. 20 世纪90年代以来越南天然橡胶产业政策探 析 [J]. 东南亚研究, (3): 33-38, 78. [Guo Y X. 2011. The natural rubber policy of Vietnam since 1990s: A primary survey[J]. Southeast Asian Studies, (3): 33-38, 78.]

李鹏, 封志明. 2016. 地缘经济背景下的老挝橡胶林地扩张 监测及其影响研究综述 [J]. 地理科学进展, 35(3): 286294. [Li P, Feng Z M. 2016. Review of remote sensing monitoring and socioeconomic and environmental impacts of rubber plantation expansion in Laos in the geoeconomic context[J]. Progress in Geography, 35(3): 286-294.]

刘少军, 张京红, 蔡大金金, 等. 2015. 海南岛天然橡胶产量灾 损风险区划[J]. 自然灾害学报, 24(2): 235-241. [Liu S J, Zhang J H, Cai D X, et al. 2015. Risk regionalization of rubber plant yield loss in Hainanisland[J]. Journal of Natural Disasters, 24(2): 235-241.]

刘少军, 周广胜, 房世波. 2016. 中国橡胶种植北界 [J]. 生态 学报, 36(5): 1272-1280. [Liu S J, Zhou G S, Fang S B. 2016. Apreliminary study of the northern planting boundary of rubber tree cultivationin China[J]. Acta Ecologica Sinica, 36(5): 1272-1280.]

王伟红, 曹新向, 苗长虹. 2009. 近 10 年来河南省人境和国内 游客的空间聚集性分析 [J]. 经济地理, 29(6): 1011-1017. [Wang W H, Cao X X, Miao C H. 2009. A study of spatial centralization of domestic and inbound tourists in Henan Province in the nearly past decade[J]. Economic Geography, 29(6): 1011-1017.]

肖池伟, 刘影, 李鹏. 2015. 近 20 年江西省水稻生产优势与时 空变化分析[J]. 农业现代化研究, 36(5): 727-735. [Xiao C W, Liu Y, Li P. 2015. Comparative advantage and its spatiotemporal changes of rice production in Jiangxi Province in past 20 years $[\mathrm{J}]$. Research of Agricultural Modernization, 36(5): 727-735.]

张赛丽, 过建春, 柯佑鹏. 2011. 世界天然橡胶的贸易格局分 析 [J]. 农业研究与应用, (4): 43-48. [Zhang S L, Guo J C, Ke Y P. 2011. Pattern of world trade in natural rubber[J]. Agricultural Research and Application, (4): 43-48.]

Baird I G. 2010. Land, rubber and people: Rapid agrarian changes and responses in southern Laos[J]. The Journal of
Lao Studies, 1(1): 1-47.

Dararath Y, Top N, Lic V. 2011. Rubber plantation development in Cambodia: At what cost[R]. Penang, Malaysia: Economy and Environment Program for Southeast Asia: 53.

Dong J W, Xiao X M, Chen B Q, et al. 2013. Mapping deciduous rubber plantations through integration of PALSAR and multi-temporal Landsat imagery[J]. Remote Sensing of Environment, 134: 392-402.

Evans T P, Phanvilay K, Fox J, et al. 2011. An agent-based model of agricultural innovation, land-cover change and household inequality: The transition from swidden cultivation to rubber plantations in Laos PDR[J]. Journal of Land Use Science, 6(2-3): 151-173.

Fox J, Castella J C. 2013. Expansion of rubber (Hevea brasiliensis) in Mainland Southeast Asia: What are the prospects for smallholders[J]. The Journal of Peasant Studies, 40(1): 155-170.

Hicks C, Voladeth S, Shi W Y, et al. 2009. Rubber investments and market linkages in Lao PDR: Approaches for sustainability[R]. Bangkok, Thailand: The Sustainable Mekong Research Network: 167.

Kitchen N. 2012. Executive summary: The new geopolitics of Southeast Asia[R]. London, UK: London School of Economics and Political Science.

Laungaramsri P. 2012. Frontier capitalism and the expansion of rubber plantations in southern Laos[J]. Journal of Southeast Asian Studies, 43(3): 463-477.

Li P, Zhang J H, Feng Z M. 2015. Mapping rubber tree plantations using a Landsat-based phenological algorithm in Xishuangbanna, southwest China[J]. Remote Sensing Letters, 6(1): 49-58.

Li Z, Fox J M. 2011. Rubber tree distribution mapping in northeast Thailand[J]. International Journal of Geosciences, 2(4): 573-584.

Li Z, Fox J M. 2012. Mapping rubber tree growth in mainland Southeast Asia using time-series MODIS $250 \mathrm{~m}$ NDVI and statistical data[J]. Applied Geography, 32(2): 420-432.

Liu X N, Feng Z M, Jiang L G, et al. 2013. Rubber plantation and its relationship with topographical factors in the border region of China, Laos and Myanmar[J]. Journal of Geographical Sciences, 23(6): 1019-1040.

Mann C C. 2009. Addicted to rubber[J]. Science, 325: 564-566. 


\title{
Spatiotemporal changes of global rubber production during 1961-2013
}

\author{
XIAO Chiwei ${ }^{1,2}$, FENG Zhiming ${ }^{1}$, LI Peng ${ }^{1 *}$ \\ (1. Institute of Geographic Sciences and Natural Resources Research, CAS, Beijing 100101, China; \\ 2. University of Chinese Academy of Sciences, Beijing 100049, China)
}

\begin{abstract}
Natural rubber is one of the four main raw materials (steel, petroleum, coal, and rubber) of industry and a globally important strategic material. Using concentration index and two-way analysis of variance method and the rubber production data of 1961-2013 at provincial, national and global scales from the Food and Agriculture Organization Corporate Statistical Database (FAOSTAT), we quantified the spatial and temporal patterns and change of rubber production and investigated the main influencing factors of these changes. The results show that: (1) Since 1961, the global total rubber production has achieved great development, showing an overall increasing trend. The rubber production of the major rubber-producing countries of Asian (MRPCA) accounted for more than $90 \%$ of global output, with a clear multi-stage growth trend in 1961-2013. (2) Spatially, rubber production showed a concentrated pattern in the MRPCA, especially in Southeast Asia, including the most concentrated countries of Thailand, Malaysia, and Indonesia. The disparities of national rubber production were significant among the MRPCA and the gaps further expanded during this time period. (3) The main factor affecting rubber production was plantation area. But in a few countries such as China and Thailand, rubber production was mainly impacted by rubber yield. (4) Global rubber production changes from "big three (Thailand, Malaysia, and Indonesia)" to a "dual core (Thailand and Indonesia)" distribution. Rubber plantations of the MRPCA generally expanded northward from the countries of island Southeast Asia to the counterparts in mainland Southeast Asia. The latter has become an advantage region in major rubber producing area of the world that shows great potential.
\end{abstract}

Key words: rubber production; spatiotemporal pattern; regional difference; Southeast Asia 